\title{
ANALISIS KONFLIK KELUARGA-PEKERJAAN SERTA PENGARUHNYAT ERHADAP KINERJA KARYAWAN WANITA PADA PERUSAHAAN DAERAH AIR MINUM (PDAM) TIRTA KHATULISTIWA KOTA PONTIANAK
}

\author{
Sulistiowati (sulistiowati.soeharso@gmail.com) \\ Fakultas Ekonomi Universitas Tanjungpura Pontianak
}

\begin{abstract}
ABSTRAK
Adanya tekanan ekonomi dan pendidikan wanita yang semakin maju mendukung semakin banyak wanita yang terjun ke dunia pekerjaan. Hal ini menyebabkan banyak wanita yang emainkan peran ganda dalam kehidupannya, yaitu peran sebagai pekerja dan peran sebagai istri/ ibu rumah tangga yang merupakan kodratnya, adanya peran ganda ini tak jarang menimbulkan konflik karena terbaginya perhatian terhadap masing-masing peran. Di saat melakukan perannya sebagai pekerja tak jarang pekerja wanita harus memikirkan juga masalah-masalah keluarga, sebaliknya saat menjalankan perannya sebagai ibu rumah tangga tak jarang pekerjaan-pekerjaan kantor yang belum selesai mengambil sebagian waktu dan pikirannya.

Tujuan penelitian ini adalah untuk mengetahui pengaruh konflik keluarga-pekerjaan terhadap kinerja karyawan wanita pada Perusahaan Daerah Air Minum (PDAM) Tirta Khatulistiwa Kota Pontianak. Penelitian ini menggunakan metode atau desain penelitian kausalitas. Sampel penelitian ini sebanyak 43 karyawan khususnya wanita sudah menikah yang menggunakan metode sampel sensus. Data dikumpulkan dengan kuesioner dan menggunakan analisis regresi linear berganda. Hasil penelitian ini menunjukkan bahwa: (1) Secara parsial, terdapat satu variabel yang terbukti secara signifikan mempengaruhi kinerja, yakni variabel tekanan perkawinan. (2) Secara simultan tidak ada pengaruh signifikan antara tekanan sebagai orang tua, tekanan perkawinan, kurangnya keterlibatan sebagai istri, kurangnya keterlibatan sebagai orangtua, dan campur tangan pekerjaan terhadap kinerja.
\end{abstract}

Kata Kunci: Konflik keluarga-pekerjaan, kinerja karyawan

\section{LATAR BELAKANG}

Masyarakat Indonesia pada umumnya masih beranggapan bahwa tanggung jawab mencari nafkah harus diemban oleh pria, namun keadaan perekonomian rumah tangga sering kali mengharuskan perempuan ikut mencari nafkah di luar rumah. Perempuan yang bekerja menyebabkan adanya perubahan baik dalam kehidupan keluarganya maupun kehidupan pribadi perempuan tersebut. Secara ekonomi, pasangan suami istri yang bekerja, atau biasanya disebut dengan istilah two workers family, menyebabkan peningkatan kesejahteraan hidup keluarga. Adanya ekstra pendapatan yang diterima menyebabkan daya beli keluarga semakin besar untuk memenuhi kebutuhan keluarga, termasuk pendidikan anak. Dalam kehidupan pribadi, perempuan yang bekerja cenderung memiliki 'bargaining power' yang lebih besar, atau dengan kata lain pendapat mereka lebih diperhitungkan dalam pengambilan keputusan dalam keluarga.

Tidak hanya keadaan ekonomi yang memaksa wanita untuk bekerja di luar rumah namun juga perkembangan pesat di segala yang terjadi di segala bidang. Ditengah semakin besarnya kesempatan bekerja bagi wanita di berbagai bidang pekerjaan serta mengeyam pendidikan tinggi, masih sering terdengar cerita bahwa wanita lebih sering memilih berhenti bekerja atau berhenti kuliah terutama setelah berkelvarga. Ada berbagai alasan yang dikemukan atas tindakan ini salah satunya untuk menjalani kodrat menjadi istri dan ibu rumah tangga. 
Perempuan yang bekerja di luar rumah otomatis mengemban peran ganda. Peran sebagai ibu rumah tangga dan peran sebagai pekerja (karyawan, pengusaha, atau professional). Urusan pekerjaan dan urusan keluarga akan saling berkaitan dalam dirinya. Hal ini seringkali memacu timbulnya konflik dalam dirinya karena membagi tenaga, waktu, dan pikiran antara urusan pekerjaan dan keluarga. Perempuan bekerja tetap dituntut untuk menjalankan kegiatan mereka dalam rumah tangga. Dapat dikatakan walaupun suami-istri sama-sama bekerja, perempuan dituntut untuk bertanggung jawab lebih besar dalam kegiatan rumah tangga dibanding laki-laki.

Seorang wanita yang sudah menikah mempunyai peran atau fungsi yang sangat banyak dalam kehidupannya dan harus menjalankan banyak tugas secara sekaligus, mulai dari mengurus suami, merawat dan mendidik anak, serta mengatur rumah tangga. Belum lagi jika seorang ibu rumah tangga itu berpartisipasi dalam dunia kerja sehingga secara otomatis seorang wanita dituntut untuk berperan sebagai ibu rumah tangga dan sekaligus wanita bekerja. Hal ini membuat intensitas peran yang dijalani oleh kaum wanita bertambah dan menuntut wanita untuk dapat memikul tugas yang lebih besar dan responsif, sehingga memunculkan konsep tentang wanita berperan ganda. Sebagai ibu rumah tangga, wanita dituntut untuk berpusat pada orang lain, pasif dan terutama mementingkan kebutuhan keluarga, sedangkan sebagai wanita bekerja dituntut untuk berpusat pada diri sendiri, tegas dan mementingkan pekerjaannya. Apa yang harus dilakukan pada kedua peran tersebut juga seringkali bertentangan. Sulitnya menyeimbangkan urusan keluarga dan pekerjaan dapat menimbulkan konflik keluarga - pekerjaan, dimana urusan keluarga mengganggu kehidupan pekerjaan, yang pada akhirnya hal tersebut dapat mengganggu bahkan mempengaruhi kinerja mereka sebagai karyawan.

\section{TINJAUAN PUSTAKA}

\section{Konflik Peran Ganda}

Menurut Davis dan Newstrom (1996) peran diwujudkan dalam perilaku. Peran adalah bagian yang dimainkan individu pada setiap keadaan dan cara tingkah lakunya untuk menyelaraskan diri dengan keadaan. Wanita bekerja menghadapi situasi rumit yang menempatkan posisi mereka di antara kepentingan keluarga dan kebutuhan untuk bekerja. Muncul sebuah pandangan bahwa perempuan ideal adalah superwoman atau supermom yang sebaiknya memiliki kapasitas yang dapat mengisi bidang domestik dengan sempurna dan bidang publik tanpa cacat. Dalam perjuangan menuju keseimbangan kerja dan keluarga inilah maka bermunculan berbagai konflik dan masalah yang harus dihadapi dan dicari jalan keluarnya jika ingin tetap menjalani kedua peran tersebut.

Bekerja adalah kegiatan yang dilakukan oleh seseorang baik secara langsung maupun tidak langsung untuk mendapatkan penghasilan dalam bentuk uang atau barang, mengeluarkan energi dan mempunyai banyak kegiatan diluar rumah, kegiatan dimana memungkinkan mereka memperoleh penghasilan bagi keluarganya sebenarnya bukanlah gejala yang baru dalam masyarakat kita (Ihromi, 1990). Dalam pengertian ini termasuk istri sendiri atau bersama suami berusaha untuk memperoleh penghasilan, dengan demikian wanita yang bekerja dapat dianggap berperan ganda. Secara umum, disesuaikan dengan keadaan sosial budaya yang tumbuh dan berkembang di Indonesia selama ini dapat disimpulkan bahwa ada tiga tugas utama wanita dalam rumah tangga yaitu:

a. Sebagai istri, supaya dapat mendampingi suami sebagai kekasih dan sahabat untuk bersama membimbing keluarga yang bahagia.

b. Sebagai pendidik, untuk pembina generasi muda supaya anak-anak dibekali kekuatan rohani maupun jasmani yang berguna bagi nusa dan bangsa 
c. Sebagai ibu rumah tangga, supaya mempunyai tempat aman dan teratur bagi seluruh anggota keluarga.

Konflik peran ganda muncul apabila wanita merasakan ketegangan antara peran pekerjaan dengan peran keluarga, Greenhaus dan Beutell (1985) dalam Aryati (2003) ada tiga macam konflik peran ganda yaitu:

a. Time-based conflict. Waktu yang dibutuhkan untuk menjalankan salah satu tuntutan (keluarga atau pekerjaan) dapat mengurangi waktu untuk menjalankan tuntutan yang lainnya (pekerjaan atau keluarga)

b. Strain-based conflict. Terjadi tekanan dari salah satu peran mempengaruhi kinerja peran lainnya.

c. Behavior-based conflict. Berhubungan dengan ketidaksesuaian antara pola perilaku dengan yang diinginkan oleh kedua bagian (pekerjaan atau keluarga).

\section{Konflik Keluarga-Pekerjaan (family-work conflict)}

Menurut Winardi (1994:8) dalam Konflik dapat muncul karena kelebihan beban peranan (role overloads) dan ketidak mampuan peranan orang yang bersangkutan (person role incompatibilities). Konflik dapat muncul bila orang mendapatkan beban berlebihan atau apabila menerima terlampau banyak tanggung jawab. Ini juga mungkin berkembang sebagai konflik nilai-nilai antara aktivitas-aktivitas kerja dan tanggung jawab keluarga.

Terjadinya perubahan demografi tenaga kerja seperti peningkatan jumlah wanita bekerja dan pasangan yang keduanya bekerja telah mendorong terjadinya konflik antara pekerjaan dan kehidupan keluarga, hal ini membuat banyak peneliti yang tertarik untuk meneliti sebab pengaruh dari konflik pekerjaan-keluarga (work-family conflict) tersebut judge et al, (1994). Greenhaus dan Beutell (1985) dalam Wirakristama (2011) mendefinisikan konflik pekerjaan keluarga sebagai bentuk konflik peran dimana tuntutan peran pekerjaan dan keluarga secara mutual tidak dapat disejajarkan dalam beberapa hal.

Hal ini biasanya terjadi pada saat seseorang berusaha memenuhi tuntutan peran dalam pekerjaan dan usaha tersebut dipengaruhi oleh kemampuan orang yang bersangkutan untuk memenuhi tuntutan keluarganya atau sebaliknya, dimana pemenuhan tuntutan peran dalam keluarga dipengaruhi oleh kemampuan orang tersebut dalam memenuhi tuntutan dengan tekanan yang berasal dari beban kerja yang berlebihan dan waktu seperti pekerjaan yang harus diselesaikan terburu-buru dan deadline sedangkan tuntutan keluarga berhubungan dengan waktu yang dibutuhkan untuk menangani tugas-tugas rumah tangga, yang dirasa pekerjaan rumah juga dianggap tidak mudah untuk dijalani jika keduanya dijaankan dalam waktu yang sama.

Peran ini ditentukan oleh masyarakat, tetapi peranan dalam tiap keluarga diperkuat oleh perasaan-perasaan, dimana perasaan-perasaan tersebut sebagai berkembangnya berdasarkan tradisi dan sebagian berdasarkan pengalaman dari masing-masing anggota kelvarga.

Frone, Rusell \& Cooper (1992) dalam Wirakristama (2011) mendefinisikan konflik pekerjaankeluarga sebagai konflik peran yang terjadi pada karyawan, dimana di satu sisi ia harus melakukan pekerjaan di kantor dan di sisi lain harus memperhatikan keluarga secara utuh, sehingga sulit membedakan antara pekerjaan mengganggu keluarga dan keluarga mengganggu pekerjaan. Pekerjaan mengganggu keluarga, artinya sebagian besar waktu dan perhatian dicurahkan untuk melakukan pekerjaan sehingga kurang mempunyai waktu untuk keluarga. Definisi tersebut dapat terjadi pula pada konflik kelvarga-pekerjaan yang artinya sebaliknya yaitu keluarga mengganggu pekerjaan berarti sebagian besar waktu dan 
perhatiannya digunakan untuk menyelesaikan urusan keluarga sehingga mengganggu pekerjaan.

Konflik keluarga-pekerjaan ini terjadi ketika kehidupan rumah seseorang berbenturan dengan tanggung jawab ditempat kerjanya, seperti menyelesaikan tugas harian rumah (rutinitas), menjaga anak atau tuntutan kehidupan rumah yang menghalangi seseorang untuk meluangkan waktu untuk pekerjaannya atau kegiatan yang berkenaan dengan kariernya, dan sebaliknya jika bekerja di perusahaann akan berbenturan dengan tanggung jawabnya untuk masuk kerja tepat waktu, menyelesaikan tugas harian sesuai target, atau kerja lembur.

Menurut Aryati (2003), tuntutan pekerjaan berhubungan dengan tekanan yang berasal dari beban kerja yang berlebihan dan waktu, seperti pekerjaan yang harus diselesaikan terburuburu dan deadline. Menurut Frone, Russell dan Cooper (1992) indikator-indikator konflik keluargapekerjaan adalah:

1. Tekanan sebagai orang tua

Tekanan sebagai orang tua merupakan beban kerja sebagai orang tua didalam keluarga. Beban yang ditanggung bisa berupa beban pekerjaan rumah tangga karena anak tidak dapat membantu dan kenakalan anak.

\section{Tekanan perkawinan}

Tekanan perkawinan merupakan beban sebagai istri didalam keluarga. Beban yang ditanggung bisa berupa pekerjaan rumah tangga karena suami tidak dapat atau tidak bisa membantu, tidak adanya dukungan suami dan sikap suami yang mengambil keputusan tidak secara bersamasama.

3. Kurangnya keterlibatan sebagai istri

Kurangnya keterlibatan sebagai istri mengukur tingkat seseorang dalam memihak secara psikologis pada perannya sebagai pasangan (istri). Keterlibatan sebagai istri bisa berupa kesediaan sebagai istri untuk menemani suami dan sewaktu dibutuhkan suami.

4. Kurangnya keterlibatan sebagai orang tua

Kurangnya keterlibatan sebagai orang tua mengukur tingkat seseorang dalam memihak perannya sebagai orang tua. Keterlibatan sebagai orang tua untuk menemani anak dan sewaktu dibutuhkan anak.

5. Campur tangan pekerjaan

Campur tangan pekerjaan menilai derajat dimana pekerjaan seseorang mencampuri kehidupan kelvarganya. Campur tangan pekerjaan bias berupa persoalan-persoalan pekerjaan yang mengganggu hubungan di dalam keluarga yang tersita.

\section{Kinerja}

Kinerja adalah hasil yang diperoleh oleh suatu organisasi baik organisasi tersebut bersifat profit oriented dan non profit oriented yang dihasilkan selama satu periode waktu (Fahmi,2010:2). Secara lebih tegas Amstrong dan Baron yang dikutip oleh Fahmi (2010:6) mengatakan Kinerja merupakan hasil pekerjaan yang mempunyai hubungan kuat dengan tujuan strategis organisasi, kepuasan konsumen dan memberikan kontribusi ekonomi. Lebih jauh Bastian yang dikutip oleh Fahmi (2010:6) menyatakan bahwa kinerja adalah gambaran mengenai tingkat pencapaian pelaksanaan suatu kegiatan/program/kebijaksanaan dalam mewujudkan sasaran, tujuan, misi, dan visi organisasi yang tertuang dalam perumusan skema strategis (strategic planning) suatu organisasi.

Menurut As'ad (1997:47) "Kinerja adalah hasil yang dicapai seseorang menurut ukuran yang berlaku untuk pekerjaan yang bersangkutan". Kesempatan dalam menghasilkan kinerja karyawan adalah fungsi interaksi dari ability (kemampuan), motivation (motivasi), opportunity (kesempatan).

Hasibuan (2002:94) mengemukakan "kinerja (prestasi kerja) adalah suatu hasil kerja yang dicapai seseorang dalam melaksanakan tugas-tugas yang dibebankan kepadanya yang didasarkan atas kecakapan, pengalaman dan kesungguhan serta waktu". Rivai (2006:309) 
mengemukakan kinerja adalah perilaku yang nyata yang ditampilkan setiap orang sebagai prestasi kerja yang dihasilkan oleh karyawan sesuai dengan perannya dalam perusahaan.

Berdasarkan keterangan diatas maka kinerja adalah prestasi kerja atau hasil kerja (output) baik kuantitas maupun kualitas kerja, kombinasi dari kemampuan dan kesempatan yang dihasilkan oleh karyawan yang dibandingkan dengan target kerja yang ditentukan.

Ada hubungan kuat antara kinerja dan prestasi kerja, ini sebagaimana yang dikemukakan oleh Erwin yang dikutip oleh Fahmi (1988:6), bahwa kinerja adalah prestasi kerja. Dan lebih jauh menurut Peter dan Salim yang dikutip oleh Fahmi (1988:6) " prestasi kerja merupakan hasil kerja yang diperoleh dari melaksanakan tugas yang dibebankan kepada seseorang".

Dalam melihat kinerja seorang karyawan perlu terlebih dahulu ditetapkan standar kinerja atau indikator kinerja yang akan digunakan sebagai parameter untuk menilai kinerja. Menurut Wibowo (2007:323), ukuran kinerja merupakan alat ukur yang harus bersifat objektif, sehingga diperlukan adanya kriteria yang sama. Dengan kriteria yang sama diharapkan memberikan hasil yang dapat diperbandingkan secara objektif dan adil. Kriteria ukuran kinerja menurut Amstrong dan Baron yang dikutip Wibowo (2007:323-324) seharusnya: (1) dikaitkan dengan tujuan strategis dan mengukur apa yang secara organisasional penting dan mendorong kinerja bisnis, (2) relevan dengan sasaran dan akuntabilitas tim dan individu yang berpentingan, (3) memfokuskan pada output yang terukur dan penyelesaian tugas dan bagaimana orang bertindak dan bagaimana tingkah lakunya, (4) mengindikasi data yang akan tersedia sebagai dasar pengukuran, (5) dapat didiversifikasi dengan menguasakan informasi yang akan mengonfirmasi tingkat seberapa jauh harapan dapat dipenuhi, (6) menjadi setepat mungkin dalam hubungan dengan maksud pengukuran dan ketersediaan data, (7) mengusahakan dasar untuk umpan balik dan tindakan, dan (8) bersifat komprehensif, mencakup semua aspek kinerja sehingga keluar ukuran tersedia.

Menurut Drucker yang dikutip Stoner dan Freeman (1992:6), kinerja karyawan dapat dinilai dari dua sudut pandang, yaitu efisien dan efektivitas kerja. Sudut efisiensi kerja mengacu kepada penyelesaian pekerjaan dengan benar dalam waktu yang relatif singkat, sehingga tenaga dan biaya yang dikeluarkan seminim mungkin, sedangkan efektivitas kerja mengacu kepada penyelesaian pekerjaan secara benar, walaupun dengan tenaga dan biaya tinggi.

Lebih lanjut Drucker yang dikutip Stoner dan Freeman mengungkapkan bahwa dalam mengendalikan kenerja pegawai, perlu ditinjau dari lima dimensi. Pertama, dimensi fisiologi. Manusia akan bekerja dengan baik apabila bekerja dalam berbagai konfigurasi operasional, yakni bekerja dengan berbagai tugas-tugas dan ritme kecepatan yang sesuai dengan fisiknya. Kedua, dimensi psikologis. Dalam hubungan ini, bekerja merupakan ungkapan kepribadian. Seseorang memperoleh kepuasan dari perkerjaannya akan menampilkan kinerja (performance) yang lebih baik dari pada mereka yang tidak menyenangi pekerjaannya. Ketiga, dimensi sosial. Bekerja dapat dipandang sebagai suatu ungkapan hubungan sosial di antara sesama pagawai. Situasi yang menyebabkan perpecahan antar pegawai dapat menurunkan kinerja pegawai, baik secara individu maupun secara kelompok. Keempat, dimensi ekonomi. Bekerja adalah kehidupan bagi pegawai, imbalan jasa yang tidak sepadan dapat menghambat atau memacu pegawai untuk berprestasi. Kelima, dimensi keseimbangan. Dalam hubungan ini keseimbangan antara apa yang diperoleh dari pekerjaan dengan kebutuhan hidup akam memacu seseorang untuk berusaha lebih giat guna mencapai keseimbangan atau sebaliknya. Dimensi ini juga disebut sebagai dimensi kekuasaan pekerjaan karena ketidakseimbangan dapat menimbulkan konflik yang dapat menurunkan kinerja.

Menurut Hasibuan (2002:55), faktor-faktor yang mempengaruhi kinerja adalah kecakapan, pengalaman, dan kesungguhan. Sementara itu Bernardin dan Rusel dalam Rucky (2000:340), mengemukakan enam kriteria primer yang dapat digunakan untuk mengukur kinerja karyawan, yaitu: (1) Quality, merupakan tingkat sejauh mana proses atau hasil pelaksanaan pekerjaan mendekati kesernpurnaan atau mendekati tujuan yang diharapkan, (2) Quantity, merupakan jumlah yang dihasilkan, misalnya jumlah rupiah, jumlah unit atau jumlah siklus 
kegiatan yang diselesaikan, (3) Timeliness, merupakan lamanya suatu kegiatan diselesaikan pada waktu yang dikehendaki, dengan memperhatikan jumlah output lain serta waktu yang tersedia untuk kegiatan lain, (4) Cost effectiveness, besarnya penggunaan sumber daya organisasi guna mencapai hasil yang maksimal atau pengurangan kerugian pada setiap unit penggunaan sumberdaya, (5) Need for supervision, kemampuan karyawan untuk dapat melaksanakan fungsi pekerjaan tanpa memerlukan pengawasan seorang supervisor untuk mencegah tindakan yang tidak diinginkan, (6) Interpersonal impact, kemampuan seorang karyawan untuk memelihara harga diri, nama baik dan kemampuan bekerjasama diantara rekan kerja dan bawahan. Unsur prestasi karyawan yang dinilai oleh setiap organisasi atau perusahan tidaklah selalu sama, tetapi pada dasarnya unsur-unsur yang dinilai itu mencakup seperti hal-hal di atas.

Dalam rangka untuk mengetahui sejauh mana pencapaian kinerja dalam suatu organisasi biasanya dilakukan kegiatan penilaian kinerja. Penilaian kinerja, menurut Dessler (2009:212), adalah "evaluating an employee's current and/or past performance relative to his or here performance standards. Batasan ini menjelaskan bahwa penilaian kinerja adalah evaluasi kinerja relatif karyawan saat ini dan atau yang telah berlalu terhadap standar kerjanya. Pengertian lain dikemukakan Hammer yang dikutip oleh Schermerhorn, Hunt dan Osborn (2005:168) bahwa penilaian kinerja adalah "a process of systematically evaluating performance and providing feedback on which performance adjustments can be made. Definisi ini menunjukkan bahwa penilaian kinerja adalah suatu proses menilai kinerja secara sistematis dan memberikan umpan balik atas penilaian kinerja yang telah dibuat.

Dalam melakukan penilaian kinerja, ada beberapa metode yang dapat digunakan. Pertama, rangking (ranking); yaitu teknik perbandingan dari penilaian kinerja yang meliputi urutan rangking dari yang terbaik sampai yang terburuk untuk masing-masing dimensi kinerja. Kedua, perbandingan berpasangan (paired comparison); yakni metode perbandingan dari penilaian kinerja dimana masing-masing orang dibandingkan secara langsung dengan orang lainnya. Ketiga, distribusi yang dipaksakan (forced distribution); adalah metode penilaian kinerja yang menggunakan sejumlah kecil kategori kinerja, seperti sangat baik, baik, cukup, dan buruk yang menekankan pada proporsi tertentu dari masing-masing orang. Keempat, skala rating grafis (graphic rating scales); adalah suatu skala yang berisi dimensi bervariasi yang dihubungan dengan kinerja tinggi dalam tugas yang diberikan dan individu diharapkan dapat mencapainya. Kelima, kejadian kritis harian (cirtical incident diary); ialah suatu metode penilaian kinerja yang mencatat kejadian-kejadian dari kesuksesan yang tidak biasa dan kegagalan pada aspek kinerja yang diberikan. Keenam, skala rating jangkar perilaku (scales rating anchored behaviorally); yaitu pendekatan penilaian kinerja yang menjelaskan perilaku kerja yang dapat diobservasi, masing-masing dinilai untuk menentukan kinerja baik dengan kinerja buruk.

Sebagai variabel terikat (dependent), eksistensi kinerja tidak terjadi begitu saja, melainkan dipengaruhi oleh banyak faktor/variabel. Menurut Gibson, et al. (2001:142), ada tiga variabel yang mempengaruhi kinerja. Pertama, variabel individual, yang terdiri dari kemampuan dan keterampilan (mental dan fisik), latar belakang (keluarga, tingkat sosial, penggajian), demografis (umur, asal-usul, jenis kelamin). Kedua, variabel organisasional, yang meliputi sumberdaya, kepemimpinan, imbalan, struktur dan desain pekerjaan. Ketiga, variabel psikologis, yang mencakup: persepsi, sikap, kepribadian, belajar, dan motivasi.

\section{PENGEMBANGAN HIPOTESIS}

Konflik keluarga-pekerjaan dapat mempengaruhi kinerja karyawan dalam suatu perusahaan. Konflik adalah persaingan yang kurang sehat berdasarkan ambisi dan sikap emosional dalam memperoleh kemenangan yang dapat menimbulkan ketegangan, konfrontasi, pertengkaran, stress dan frustasi apabila masalah mereka tidak dapat diselesaikan.

Hal ini penting untuk diketahui oleh perusahaan agar dapat mengambil tindakantindakan pencegahan. Begitu juga dengan konflik keluarga-pekerjaan terhadap wanita yang 
sudah menikah atau berkeluarga. Konflik keluarga-pekerjaan berhubungan positif dengan kinerja karyawan, rendahnya tingkat kinerja yang berhubungan dengan hasil kerja karyawan tersebut pada suatu peran bisa dialami bila seseorang sering kali gagal memenuhi peran tersebut karena karyawan di dalam keluarganya dapat mengganggu pekerjaannya. Karyawan yang mengalami tingkat konflik keluarga-pekerjaan yang tinggi melaporkan menurunnya kinerja karena merasa lebih dikuasai oleh masalah dalam keluarganya yang mengakibatkan karyawan tidak bisa memenuhi tanggung jawab pekerjaannya secara maksimal, karena mengurangi kualitas pekerjaannya.

Penelitian terdahulu yang dilakukan oleh Indriyani (2007) dengan judul "Pengaruh Konflik Peran Ganda dan Stres Kerja Terhadap Kinerja Perawat Wanita Rumah Sakit, Studi Pada Rumah Sakit Roemani Muhammadiyah Semarang". Menyimpulkan bahwa konflik keluarga-pekerjaan terhadap kinerja perawat berpengaruh signifikan positif terhadap terjadinya stres kerja mempunyai pengaruh sebesar -0,58 terhadap kinerja perawat dengan tingkat signifikan yang baik, hasil ini sesuai dengan hipotesis bahwa semakin tinggi tingkat konflik keluarga-pekerjaan maka akan mengurangi kinerja perawat rumah sakit.

Wirakristama (2011), penelitian yang dilakukan pada PT. Nyonya Meneer di kota Semarang. Metode pengumpulan data pada penelitian ini adalah dengan kuesioner yang diisi oleh responden yaitu karyawan wanita di PT. Nyonya Meneer yang sudah pernah menikah. Hasil analisis menggunakan uji $\dagger$ dapat diketahui konflik peran ganda (work family conflict) berpengaruh signifikan terhadap kinerja karyawan wanita PT. Nyonya Meneer Semarang dengan difokuskan pada konflik keluarga-pekerjaan.

Penelitian yang dilakukan Leftysia Josella (2012) yang menguji pengaruh konflik pekerjaan terhadap keluarga dan konflik keluarga terhadap pekerjaan dengan kinerja karyawan perempuan di PT Fabindo Sejahtera menyimpulkan bahwa karyawan perempuan kurang setuju jika konflik pekerjaan terhadap keluarga dan konflik keluarga terhadap pekerjaan mempengaruhi kinerja kerja mereka. Selain itu, hubungan antara konflik pekerjaan terhadap kelvarga dengan kinerja kerja adalah negatif, lemah, dan signifikan; sedangkan tidak ada hubungan dan tidak signifikan antara konflik keluarga terhadap pekerjaan dengan kinerja kerja. Walaupun demikian, hubungan antara konflik pekerjaan terhadap keluarga dan konflik kelvarga terhadap pekerjaan adalah positif, kuat, dan signifikan. Secara parsial, konflik pekerjaan terhadap keluarga tidak berpengaruh namun signifikan dengan kinerja kerja, sedang konflik keluarga terhadap pekerjaan tidak berpengaruh dan tidak signifikan dengan kinerja kerja. Secara simultan konflik pekerjaan terhadap keluarga dan konflik keluarga terhadap pekerjaan berpengaruh positif dan lemah terhadap kinerja kerja.

Menurut Hasibuan (2002) kinerja (prestasi kerja) adalah suatu hasil kerja yang dicapai seseorang dalam melaksanakan tugas-tugas yang dibebankan kepadanya yang didasarkan atas kecakapan, pengalaman dan kesungguhan serta waktu. Bagi wanita bekerja dan telah berkeluarga akan memiliki kinerja yang berbeda dari wanita bekerja tetapi belum berkeluarga. Hal ini dikarenakan bagi ibu bekerja, mereka harus menjalani dua peran yang berbeda yakni menjadi wanita pekerja dan sebagai ibu rumah tangga, dan bagi ibu bekerja yang tidak dapat menjalaninya dengan baik akan mengalami konflik peran ganda (Maherani, 2011).

Rozikin (2006) dalam penelitiannya menyimpulkan bahwa konflik peran dan stress kerja berpengaruh signifikan negatif terhadap kinerja karyawan, artinya semakin tinggi konflik peran dan stress kerja maka akan berdampak pada penurunan secara signifikan terhadap kinerja karyawan dan sebaliknya semakin rendah konflik peran dan stress kerja maka akan berdampak pada peningkatan secara signifikan terhadap kinerja karyawan.

Berdasarkan hal tersebut, diajukan hipotesa sebagai berikut:

$\mathrm{H1}$ : Tekanan sebagai orang tua berpengaruh signifikan terhadap kinerja karyawan wanita.

H2: Tekanan perkawinan berpengaruh signifikan terhadap kinerja karyawan wanita.

H3: Kurangnya keterlibatan sebagai istri berpengaruh signifikan terhadap kinerja karyawan wanita. 
H4: Kurangnya keterlibatan sebagai orang tua berpengaruh signifikan terhadap kinerja karyawan wanita.

H5: Campur tangan pekerjaan berpengaruh signifikan terhadap kinerja karyawan wanita.

H6: Kelima variabel konflik keluarga-pekerjaan secara bersama-sama berpengaruh signifikan terhadap kinerja karyawan wanita.

\section{Metode Penelitian}

Studi ini menggunakan indikator dari berbagai sumber. Variabel - variabel Konflik Keluarga-Pekerjaan mengacu pada pendapat Frone, Russell dan Cooper (1992) yang terdiri dari: Tekanan sebagai orang tua, dengan Indikator yang digunakan: terbebani akan kenakalan anak - anak, anak tidak dapat membantu orangtua, kesulitan mengantar anak ke sekolah, kekhawatiran orangtua ketika anak sedang sakit, kekhawatiran orangtua ketika tidak ada yang menjaga anak, perbedaan pendapat antara orangtua dan anak, ketidaknyamanan suasana dirumah. Tekanan perkawinan dengan Indikator yang digunakan: terbebani ketika suami tidak dapat memberi bantuan, kerenggangan hubungan suami-istri akibat keduanya sibuk, terbebani akan urusan rumah tangga yang hanya dibebankan kepada istri,terbebani akan penempatan kerja pasangan yang berada jauh,sikap suami yang tidak dapat membantu memecahkan masalah / membuat keputusan. kurangnya keterlibatan sebagai istri dengan indikator yang digunakan: minimnya waktu berada dirumah menimbulkan kecemasan, kelelahan yang mengakibatkan komunikasi menjadi tidak baik, sedikitnya waktu untuk menemani suami karena sibuk bekerja,peran istri menjadi minim yang membuat pasangan menjadi protes, kurangnya keterlibatan sebagai orang tua dengan indikator yang digunakan: keluhan anak ketika orangtua tidak ada waktu untuk mereka, perbedaan hari libur anak dan jam kerja yang berbeda, kesibukan orangtua akan pekerjaan yang berdampak pada anak, kesulitan anak meminta bantuan ketika orangtua sangat sibuk bekerja. Campur tangan pekerjaan dengan indikator yang digunakan: terbebani akan pekerjaan rumah yang belum selesai, terbebani akan pembagian pekerjaan rumah dan kantor.

Indikator - indikator kinerja mengacu pada pendapat Bernardin dan Rusel dalam Rucky (2000:340), yang mengemukakan enam kriteria primer yang dapat digunakan untuk mengukur kinerja karyawan, yaitu: Quality, Quantity, Timeliness, Cost effectiveness, Need for supervision, dan Interpersonal impact.

Jumlah sampel dalam studi ini sebanyak 43 orang karyawan wanita PDAM Tirta Khatulistiwa Pontianak yang telah menikah dan memiliki anak balita dan anak usia sekolah, dengan pertimbangan wanita yang memiliki anak balita dan anak usia sekolah akan cenderung mengalami konflik lebih besar dibanding karyawan wanita yang memiliki anak yang telah dewasa.

\section{ANALISA}

Tabel 1. Hasil Analisis Regresi Linear Berganda 
Sulistiowati

Sumber: Data Olahan, 2012

Berdasarkan hasil analisis pada tabel, diperoleh model regresi sebagai berikut

$$
\begin{aligned}
& Y=\quad a+b_{1} X_{1}+b_{2} X_{2}+b_{3} X_{3}+b_{4} X_{4}+b_{5} X_{5}+b_{6} X_{6}+b_{7} X_{7} \\
& Y=\quad 3,697-0,059 X_{1}+0,177 X_{2}+0,036 X_{3}-0,131 X_{4}-0,050 X_{5}
\end{aligned}
$$

Konstanta sebesar 3,697 ; artinya jika $X_{1}, X_{2}, X_{3}, X_{4}, X_{5}$ nilainya adalah 0 , maka nilai dari kinerja (Y) adalah 3,697. Koefisien regresi variabel tekanan sebagai orangtua $\left(X_{1}\right)$ sebesar 0,059; artinya jika variabel independen lain nilainya tetap dan tekanan sebagai orangtua mengalami kenaikan. Koefisien bernilai negatif, artinya terjadi hubungan negatif antara tekanan sebagai orangtua dengan kinerja, semakin naik nilai $X_{1}$ maka semakin turun nilai $Y$. koefisien regresi variabel tekanan perkawinan $\left(X_{2}\right)$ sebesar 0,177 ; artinya jika variabel independen lain nilainya tetap dan tekanan perkawinan mengalami kenaikan. Koefisien bernilai positif, artinya terjadi hubungan positif antara tekanan perkawinan dengan kinerja, semakin naik nilai $X_{2}$ maka semakin meningkatnya nilai $Y$. Koefisien regresi variabel kurangnya keterlibatan sebagi istri $\left(\mathrm{X}_{2}\right)$ sebesar 0,036; artinya jika variabel independen lain nilainya tetap dan tekanan perkawinan mengalami kenaikan. Koefisien bernilai positif, artinya terjadi hubungan positif antara kurangnya keterlibatan sebagi istri dengan kinerja, semakin naik nilai $X_{3}$ maka semakin meningkatnya nilai $Y$. Koefisien regresi variabel kurangnya keterlibatan sebagai orangtua $\left(X_{4}\right)$ sebesar -0,131; artinya jika variabel independen lain nilainya tetap dan kurangnya keterlibatan sebagai orangtua mengalami kenaikan. Koefisien bernilai negatif, artinya terjadi hubungan negatif antara kurangnya keterlibatan sebagai orangtua dengan kinerja, semakin naik nilai $X_{4}$ maka semakin turun nilai $Y$. Koefisien regresi variabel campur tangan pekerjaan $\left(X_{5}\right)$ sebesar -0,050; artinya jika variabel independen lain nilainya tetap dan campur tangan pekerjaan mengalami kenaikan. Koefisien bernilai negatif, artinya terjadi hubungan negatif antara campur tangan pekerjaan dengan kinerja, semakin naik nilai $X_{5}$ maka semakin turun nilai $Y$.

\section{Tabel 2. Hasil Analisis Determinasi}


Olahan, 2012

Nilai

determinasi

sebesar 0,238

secara

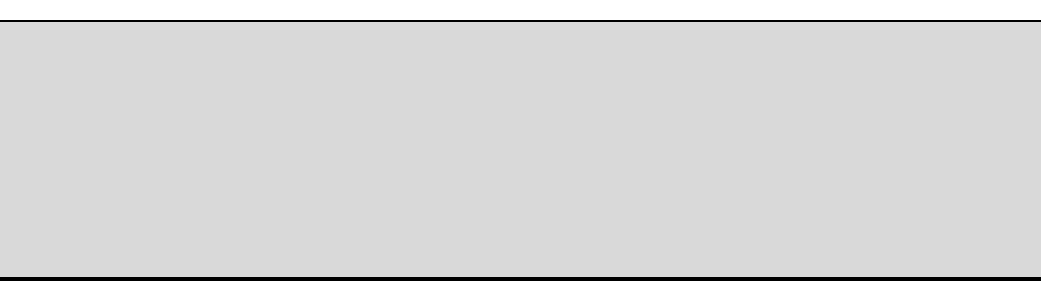

koefisien berganda $\mathrm{R}^{2}$

menunjukkan

simultan

variabel

tekanan

sebagai orang tua, tekanan perkawinan, kurangnya keterlibatan sebagai istri, kurangnya keterlibatan sebagai orangtua, dan campur tangan pekerjaan berpengaruh terhadap variabel kinerja (Y). Oleh karena itu, semakin tinggi nilai koefisien determinasi parsial semakin tinggi kontribusi variabel bebas dalam menjelaskan variabel terikat.

\section{Tabel 3. Hasil Uji †}


Sulistiowati

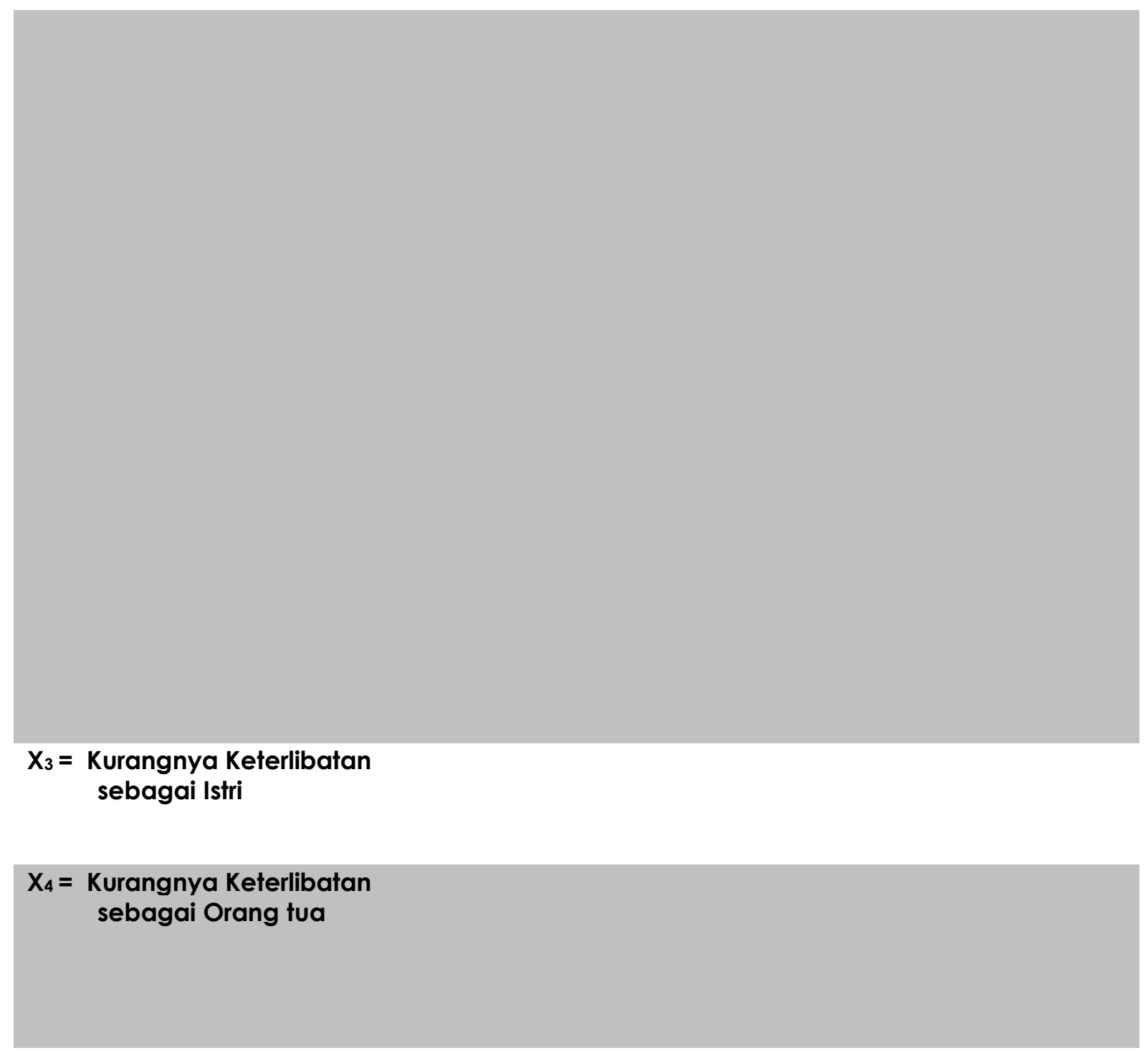


Sumber: Data Olahan, 2012

Berdasarkan hasil uji † yang telah dilakukan, diperoleh hasil bahwa variabel tekanan perkawinan $\left(X_{2}\right)$ secara parsial berpengaruh signifikan terhadap kinerja. Variabel perkawinan $\left(X_{2}\right)$, dijelaskan dengan nilai $\dagger$ hitung $>\dagger$ tabel $(2,352>1,682)$ dengan signifikansi 0,024 dan berada di bawah tingkat signifikansi $a=5 \%$, atau 0,05 , merupakan variabel yang paling berpengaruh terhadap kinerja, karena memiliki tingkat signifikansi.

\section{Tabel 4. Hasil Uji F}

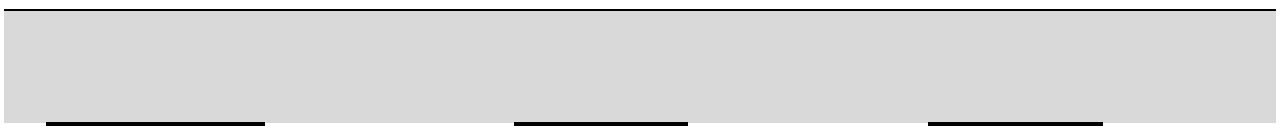




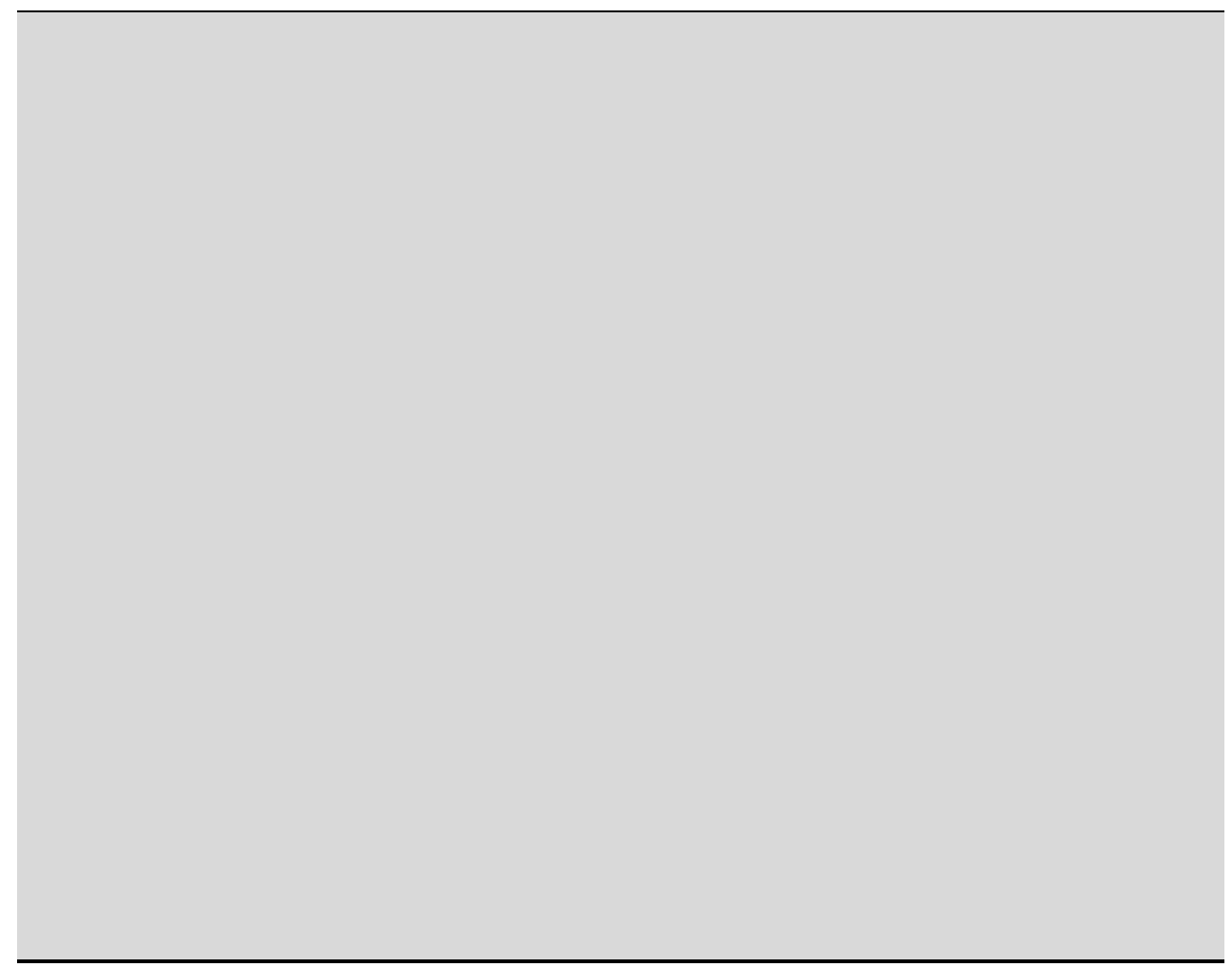

Sumber: Data Olahan, 2012

Dengan tingkat signifikansi $a=5 \%$ (atau 0,05), dapat dilihat dari tabel 3nilai signifikansi sebesar 0,063, maka Ho diterima, artinya tidak ada pengaruh signifikan antara tekanan sebagai orang tua, tekanan perkawinan, kurangnya keterlibatan sebagai istri, kurangnya keterlibatan sebagai orangtua, dan campur tangan pekerjaan secara bersama-sama terhadap kinerja.

Berdasarkan model penelitian yang dikembangkan dalam penelitian ini, maka dapat memperkuat konsep-konsep teoritis dan memberikan dukungan empiris terhadap penelitian terdahulu. Penelitian ini didukung oleh responden karyawan wanita yang sudah menikah. Hasil penelitian disimpulkan bahwa secara parsial (Uji t), terdapat 1 (satu) variabel yang terbukti secara signifikan mempengaruhi kinerja, yakni variabel tekanan perkawinan.

Hal ini dikarenakan mereka (1) merasa terbebani saat suami tidak dapat memberi bantuan ketika sangat dibutuhkan, (2) karena aktivitas yang padat (sibuk) dan kebanyakan dari mereka keduanya sibuk dalam urusan pekerjaan membuat hubungan suami istri menjadi renggang, (3) terbebani akan urusan rumah tangga yang hanya dibebankan kepada istri, (4) terbebani akan penempatan kerja pasangan yang berada jauh artinya banyak dari para istri yang tidak setuju jika suaminya dinas yang jauh dari tempat tinggal mereka (diluar kota), (5) jika sikap suami tidak dapat membantu memecahkan masalah atau tidak dapat memutuskan suatu keputusan (diskusi). Namun, untuk keempat variabel lainnya seperti variabel tekanan sebagai orang tua, kurangnya keterlibatan sebagai istri, kurangnya keterlibatan sebagai orang tua, dan variabel campur tangan pekerjaan tidak berpengaruh secara parsial.

Secara simultan atau bersama-sama (Uji F) variabel tekanan sebagai orang tua, tekanan perkawinan, kurangnya keterlibatan sebagai istri, tekanan sebagai orang tua, dan variabel campur tangan pekerjaan tidak berpengaruh signifikan terhadap kinerja karyawan.

Hal ini secara tidak langsung ketika motor penggerak perusahaan (karyawan) sedang bermasalah dan dibawa kedalam suatu organisasi/perusahaan, jika pihak perusahaan tidak menanggapi dan tidak menindak lanjutinya dengan bijak dan serius maka permasalahan yang tadinya kecil bisa menjadi besar, seperti halnya setelah dilakukan uji t hanya satu variabel yang berpengaruh signifikan ketika masalah ini tidak ada solusi maka bisa saja akan mempengaruhi 
variabel lainnya dan ini tentunya akan mempengaruhi tingkat keseriusan bekerja yang akhirnya berpengaruh pada kinerja karyawan, dapat dikatakan juga bahwa peran SDM merupakan faktor sentral dalam organisasi yang dari waktu ke waktu akan semakin startegis dan menjadi lebih diperhatikan (Foulkes:1975)

\section{SIMPULAN}

Kesimpulan yang dapat disajikan dalam penelitian ini adalah: 1.Secara parsial, terdapat 1 (satu) variabel yang terbukti secara signifikan mempengaruhi kinerja, yakni variabel tekanan perkawinan. 2. Secara simultan tidak ada pengaruh signifikan antara tekanan sebagai orang tua, tekanan perkawinan, kurangnya keterlibatan sebagai istri, kurangnya keterlibatan sebagai orangtua, dan campur tangan pekerjaan secara bersama-sama terhadap kinerja. Penelitian ini diperkuat dengan hasil penelitian terdahulu yang dilakukan oleh Indriyani (2007) dengan judul "Pengaruh Konflik Peran Ganda dan Stres Kerja Terhadap Kinerja Perawat Wanita Rumah Sakit, Studi Pada Rumah Sakit Roemani Muhammadiyah Semarang". Menyimpulkan bahwa konflik kelvarga-pekerjaan terhadap kinerja perawat berpengaruh signifikan positif terhadap terjadinya stres kerja mempunyai pengaruh sebesar -0,58 terhadap kinerja perawat dengan tingkat signifikan yang baik, hasil ini sesuai dengan hipotesis bahwa semakin tinggi tingkat konflik keluarga-pekerjaan maka akan mengurangi kinerja perawat rumah sakit.

Penelitian ini juga mendukung penelitian Wirakristama (2011), yang dilakukan pada PT. Nyonya Mener di kota Semarang. Metode pengumpulan data pada penelitian ini adalah dengan kuesioner yang diisi oleh responden yaitu karyawan wanita di PT Nyonya Meneer yang sudah pernah menikah. Hasil analisis menggunakan uji $\dagger$ dapat diketahui konflik peran ganda (work family conflict) berpengaruh signifikan terhadap kinerja karyawan wanita PT Nyonya Meneer Semarang dengan difokuskan pada konflik keluarga-pekerjaan.

\section{DAFTAR PUSTAKA}

Aryati, Nyoman Tri. 2002. Pengaruh Adaptasi Kebijakan Work-Family Issue Terhadap Absence dan Turnover. Jurnal Widya Manajemen \& Akuntansi,Vol.2, No.3 Desember 2002

As'ad, Moh. 1997 . Psikologi Industri. Edisi Kelima. Yogyakarta:Liberty.

Dhamayantie, Endang. 2008. Konsekuensi Konflik Pekerjaan-Keluarga (Work - Family Conflict) Pada Pekerja Wanita Yang Menikah Di Kota Pontianak. Pontianak: Ditlibintambas Ditjen Dikti.

Emzir. 2007. Metodelogi Peneltian Pendidikan Kuantitatif dan Kualitatif. Jakarta: Raja Gafindo Persada.

Fahmi, Irham. 2010. Manajemen Kinerja:Teori dan Aplikasi. Bandung: Alfabeta.

Frone, M.R., Russell, M., \& Cooper, M.I.,1992. Prevelence of work-family conflict : Are work and family boundaries asymmetrically permeable?. Journal of Organizational Behaviour.

Gary Dessler. 2009. Fundamental of Human Resources Management:content, cometencies and applications. New Jersey: Pearson Education,Inc.

Gibson, J.L., John M. Ivancevich, James H. Donnelly, and Robert Konopaske, 2001. Organizations: Behavior, Structure, Processes, Boston: McGraw Hill Irwin.

Indriyani, Azazah. 2009. Pengaruh Konflik Peran Ganda dan Stres Kerja terhadap Kinerja Perawat Wanita Rumah Sakit (Studi pada Rumah Sakit Roemani). Semarang: Universitas Diponegoro.

Josella, Leftysia. 2012. Analisis Pengaruh Konflik Pekerjaan dan Konflik Keluarga Terhadap Kinerja Kerja Karyawan Perempuan di PT Fabindo Sejahtera Jakarta. Unika Atmajaya. Jakarta.

Maherani, Astrani. 2011. Pengaruh Konflik Peran Ganda Dan Fear Of Success Terhadap Kinerja Wanita Berperan Ganda. Universitas Gunadarma. Jakarta 
Malayu, Hasibuan. SP. 2002. Manajemen Sumber Daya Manusia, Edisi Revisi, Jakarta:PT. Bumi Aksara.

Rivai, Veithzal. 2006. Manajemen Sumber Daya Manusia untuk Perusahaan dari Teori ke Praktek. Jakarta

Robbins, Stephen .2006. Perilaku Organisasi. PT Indeks Kelompok Gramedia.Jakarta.

Rozikin, Zainur. 2006. Pengaruh Konflik Peran dan Stres Kerja terhadap Kinerja Karyawan Pada Bank Pemerintah Kota Malang. Jurnal Aplikasi Manajemen. Volume 4. Malang.

Rucky, Achmad S .2000. Sistem Manajemen Kinerja. Jakarta: PT. Gramedia. Pustaka Utama.

Sanusi, Anwar. 2011 . Metodelogi Penelitian Bisnis. Malang: Salemba Empat.

Schermerhorn, John R., Jr, James G. Hunt dan Richard N. Osborn, 2005. Organizational Behavior, New Jersey: John Wiley \& Sons, Inc.

Soeprihanto, John, 2000. Penilaian Kinerja dan Pengembangan Karyawan, Yogyakarta: BPFE.

Stoner, James A.F. and R. Edward Freeman, 1992. Management, New York: Prentice Hall International Inc.

Sugiyono. 1999. Metode Penelitian Bisnis. Jakarta: Alfabeta.

Sugiyono. 2005. Statistika untuk Penelitian. Bandung: CV. Alfabeta.

Umar, Husein. 1999. Metodelogi Penelitian. Jakarta:Gramedia.

Umar, Husein. 2008. Riset Sumber Daya Manusia. Cetakan Kedelapan.Jakarta: Gramedia. 2002. Metode Riset Bisnis. Jakarta:Gramedia.

Wibowo. 2007. Manajajemen Kinerja. Jakarta:RajaGrafindo Persada.

Winardi, 1994. Manajemen konflik (konflik perubahan dan pengembangan), Mardar Maju, Bandung

Wirakristama, Richardus C. 2011. Analisis Pengaruh Konflik Peran Ganda (Work Family Conflict) terhadap Kinerja Karyawan Wanita pada PT. Nyonya Maneer Semarang dengan Stress Kerja sebagai Variabel Intervening. Semarang: Universitas Diponegoro.

W.S, Christine, Oktorina, Megawati, Mula, Indah. 2010. Pengaruh Konflik Pekerjaan dan Konflik Kelvarga Terhadap Kinerja dengan Konflik Pekerjaan Kelvarga Sebagai Intervening Variabel (Studi pada Dual Career Couple di Jabodetabek.) Jakarta:Fakultas Ekonomi Universitas Katolik Indonesia Atma Jaya. 